\title{
Orvostörténeti szoborpanteon a Budai Irgalmasrendi Kórházban
}

\author{
Gömör Béla dr. \\ Semmelweis Egyetem, Általános Orvostudományi Kar, a III. Belgyógyászati Klinika Reumatológiai \\ és Fizioterápiás I. Sz. Tanszéki Csoportja a Budai Irgalmasrendi Kórház telephelyén
}

A Betegápoló Irgalmasrend budai kórházát és rendházát 1903. szeptember 29-én avatták fel, amiről a centenáriuma kapcsán folyóiratunkban már volt szó [1]. A Margit híd budai hídfóje közelében, a mai Frankel Leó út 1719. szám alatt álló épületben az akkori kornak megfelelő legmodernebb kórház kezdte meg múködését, és itt kapott helyet a rend magyarországi tartományfőnöksége is. Egyébként a területen előzőleg is kórház állt, a „régi irgalmasrendi”, melynek lebontását 1901 februárjában kezdték meg. Az új épület tervei annak a Kiss István müegyetemi magántanárnak a nevéhez füződnek, aki az I. sz. női klinika Baross utcai épületét is tervezte. Az új irgalmasrendi kórház kivitelezési munkáinak irányítását azonban nem vállalta el, azt Fligauf Károly végezte el. Kiss István fiatalon, 44 éves korában, a kórház fölavatása előtti évben el is halálozott.

1935 júniusában a kórház előcsarnokában jelentős átalakítási munkák kezdődtek, melyek keretében 17 mellszobor helyét is kivésték. A Magyar Nemzeti Levéltárban tanulmányozható az irgalmasrendi iratok között megmaradt Historia Domus. Az 1935. október 11-i dátumnál remekül olvasható kézírásos bejegyzésból tudhatjuk meg, hogy aznap derús idő volt, és a kórház bejárati portálja (új szélfogó) teljesen elkészült [2]. Ekkor került átadásra a 17 darab terrakotta mellszobor is. Megvalósult a rendi szándék: „Kórházunk elöcsarnokában elbelyezni óbajtjuk az orvosi tudomány magyar nagyjait.” Ezzel az orvostörténeti panteonnal nemcsak a kórház, hanem a főváros is jelentôs múvészeti alkotásokkal gyarapodott. Az Irgalmasrend komoly mecenatúrát gyakorolt, amikor a megmintázásokkal a magyar szobrászat akkori újabb nemzedékének tagjait bízta meg. A hét szobrász névsorban: Csorba Géza, Halmágyi István, Mikus Sándor, Pátzay Pál, Szomor László, Varga Oszkár és Vilt Tibor.

A szobrokról múvészeti híradásként Mátyás Péter aláírásával cikk jelent meg: „Az Irgalmasok kórházának új szobrai” [3]. A névaláírás Kállai Ernő (1890-1954) müvészettörténész alkalmanként használt álneve. A hat reprodukciós képet Máté Olga (1878-1961) neves fotográfus készítette.

A ma is látható 13 mellszobor a magyar fővárosban múködött vezető orvosi személyiségeket ábrázolja. Fe- leslegesnek tûnik e helyen a közismert nagy orvosegyéniségekről írni, mikor kötetszámra van olvasnivaló róluk. Így a leginkább Semmelweis Ignácról (1818-1865) vagy az első közegészségügyi tanszékünk vezetőjéről, Fodor Józsefről (1843-1901), továbbá Hőgyes Endréről (1847-1906), a kórtan hírességéről nem is szólunk részletesen, s a többiekről is csak néhány érdekességgel emlékezünk meg.

A neves szülész-nőgyógyászok közül Semmelweisen kívül még ketten lelhetők föl a szoborgalériában. Kézmárszky Tivadar (1842-1902) 28 éven át volt Budapesten egyetemi tanár. Erről a szoborról írja az alkotójával, Csorba Gézával foglalkozó múvészeti kötet, hogy: „nem elégedett meg a külsö megjelenitést jellemzö vonások, a bajuszos-szakállas fej érzékletes plasztikai megformálásával, hanem emberi lelki analizisre is törekedett” [4]. Kézmárszky szakmai és emberi nagyságáról kitűnő összeállítást olvashatunk [5]. Utóda Bársony János (1860-1926) lett, aki 23 éven át vezette az I. számú női klinikát, miközben 1922/23-ban az egyetem rektora is volt. Az akkori szokás szerint, mint az egyetem első számú megválasztott vezetője, ezt a szolgálatot egy évig töltötte be.

A legnagyobb magyar sebész, Balassa János (18141868 ) mellszobra Halmágyi István egyetlen itt szereplő alkotása. Balassa 1843-tól negyedszázadon át s így a forradalom és a szabadságharc idejében is vezette az akkori sebészeti klinikát.

Tanszéki utódai közül a szobrok között Pátzay Pál alkotásaként szerepel Dollinger Gyula (1849-1937), aki ezzel a mottóval írta meg visszaemlékezéseit: „a legfiatalabb orvosnemzedék lássa meg benne, hogy a magas célhoz rögös, meredek út vezet, amelynek mentén csodás virágok is fakadnak” [6]. Atyja Karintiából bevándorolt szorgos német ember volt. A sebészet teljes vertikumával foglalkozott, de szinte kedvenc területe a csontok és egyéb mozgásszervek sebészete lett. 1889-ben fölajánlása nyomán engedélyt kapott, hogy az Irgalmas Kórházban (a régiben) saját költségén sebészeti osztályt rendezzen be. Teljes mütőterem-berendezést hozott a kórházba, elkülönített szeptikus és aszeptikus részeken operáltak. „Itt, az Irgalmasok kórházában dolgoztam ki az alsó végtagok csonttöréseinek fennjáró gyógykezelését.” 1897-ben 
elhalálozott Kovács József professzor (1832-1897), és Dollingert azonnali hatállyal megbízták a Sebészeti Klinika vezetésével, ahová 1898-ban a király ki is nevezte igazgatónak. 1919-ben vonult nyugdíjba. A hazai ortopédia megalapítójaként lehet elkönyvelni.

A másik nevezetes sebészszobor Verebélÿ Tibort (1875-1941) ábrázolja. Dollingert követte a katedrán, s haláláig töltötte be az igazgatói állást. Híres volt nagy szigorúságáról. A felsőház tagja, a Corvin-koszorú, majd a Corvin-lánc tulajdonosa. Szintén a kórház épületéhez füződő orvostörténeti adat, hogy fia, Verebélÿ Tibor 1951 és 1978 közötti osztályvezetése tette nagyhírúvé az Országos Reumatológiai és Fizioterápiás Intézet (ORFI) sebészeti osztályát.

A belgyógyászat nagyjai közül az aránylag hasonlatos mellszobrok között ma is látható báró Korányi Frigyes (1828-1913) kőbe vésett arcmása. Ö 37 éves koráig Szabolcs megyében dolgozott. A pesti, majd budapesti egyetemen 42 éven át volt klinikavezető, közben az 1886/87-es tanévben rektor. 81 éves korában nyugdíjazták.

Az említett Magyar Müvészet-beli cikk hat illusztrációja közül az egyik Jendrassik Ernő (1858-1921) Szomor László által készített szobra. Jendrassik személyes példát adott arra, hogy akkortájt milyen közel állt egymáshoz az ideggyógyászat és a belgyógyászat. Éveken át az előbbi tárgykörből képezte magát külföldön, majd magántanár lett Budapesten. A millennium évétől, tehát még a régi irgalmasrendi kórházban, a belgyógyászat és idegelme gyógyászat fóorvosa. Majd az egyetemen 1903-tól az ideggyógyászat nyilvános rendes tanára, 1909-től pedig az akkori II. Számú Belklinika (a mai I. számú épületében, a Korányi Sándor utcában) első igazgatója.

A negyedik nagy szakma, a gyermekgyógyászat képviselőjeként Bókay János (1858-1937) büsztje is föllelhető a kórházi előcsarnokban. Édesapja, a szintén gyermekgyógyász, dinasztiaalapító Bókai János volt. Bókay 1896-ban kapott nemességet a királytól, ekkor lett a Bókai névből Bókay.

Az 1817-ben múködését megkezdő „régi” irgalmasrendi kórházban gyermekosztály is volt. A kórház lebontása előtti esztendőktől, majd az új épületben még hoszszú éveken át itt múködött neves gyermekgyógyászunk, Heim Pál (1875-1929). A szerencsétlen 1918-as évben került kinevezésre a megalakuló pozsonyi egyetem orvoskarára. Útja a továbbiakban Budapestre, majd Pécsre vezetett. A fóvárosban az 1921/22-es tanévben ő lett az egyetem rektora. 1929-ben Budapestre nevezték ki Bókay helyére, de pár hónap múlva hirtelen elhalálozott. Megemlítésre érdemes, hogy Heim Pál még csak hat éve távozott az élők sorából, amikor a 17 szoborral együtt az övé is fölavatásra került az Irgalmas Kórház előcsarnokában.

Magára a kórházra vonatkozóan tehát különös jelentőséggel bír, hogy a megformált nagy orvostudorok közül három is itt múködött az egyetemi katedra elfoglalása elött.
Az I. emeleten látható egy nem orvosszobor. Jedlik Ányos bencés szerzetest Vilt Tibor alkotása mutatja be. Jedlik fizikus volt, és a dinamóelv, a villanymotor, valamint a szódavízgyártás föltalálása révén jogosan világhírü.

Nem tudni, hogy miért és mikor távolítottak el négy szobrot földszinti fülkéikből, de azok ma üresen ásítoznak.

Valaha a földszinten volt látható Gabriel Ferrara irgalmasrendi orvos-szerzetes szobra, mely további négy szoborral együtt a hét szobrász közül legjelentősebbnek mondható múvész, Pátzay Pál munkája. A 17 ábrázolt közül ő az egyetlen nem magyar. A Milánóban, 1543 táján született Camillo von Ferrara gróf orvosnak tanult, és sebész lett. Az Irgalmasrendbe 48 éves korában lépett be, Gabriel rendi névvel. Hamarosan Rómába került, majd átvehette a rend vezetési feladatait. Nagy sikerrel gyógyított királyokat, uralkodókat, s jutalmul az adott országokban, városokban - a szegények orvosi ellátása céljából - újabb irgalmasrendi kórházakat alapíthatott. 1627-ben Bécsben halálozott el.

A másik szintén Pátzay-mü viszont nem orvost ábrázol, hanem Pázmány Péter XVII. századi esztergomi érseket. Ő jezsuita szerzetes volt, nagyhatású hitszónok, akit a magyarországi katolikus megújulás vezéralakjának tartanak. Személyes adományával hozta létre a nagyszombati egyetemet.

A további két földszinti szobor Bókay Árpád (18561919) gyógyszertanász egyetemi tanárt, aki 1905-től haláláig a Magyar Balneológiai Egyesület elnöke volt, illetve Kétly Károly (1839-1927) belgyógyászt mutatta be. Az előbbi 27 éves korában foglalhatta el Hőgyes kolozsvári igazgatói helyét. Az utóbbi az 1883-ban kapuit megnyitó Szentkirályi utcai belgyógyászati klinikán először csak az „A” épületben lévő részt igazgatta (a két épület csak 1936-ban került közös irányítás alá), majd a több mint 40 éven át tanító Korányi Frigyes nyugdíjba vonulása után, 1908-tól lett az akkor még I. Számú Belklinika igazgatója. 74 éves korában adta át a helyét fiának, báró Kétly Lászlónak (1873-1936).

A szerzeteseknek, vagyis a kórház tulajdonosainak és üzemeltetőinek 1950. szeptember 7-én azonnali hatálylyal el kellett hagyniuk az épületet. Villámgyorsan következett be az államosítás, létrejött a kérészéletű Kunfi Zsigmond Kórház, mely a következő évben az Állami Reumakórházba tömörített osztályokkal egyesült, s elkezdte múködését az ORFI.

Nagy a valószínûsége annak, hogy rögtön az államosításkor távolították el a négy földszinti szobrot. De az is lehetséges, hogy a későbbiekben, például azért, mert köztük volt az irgalmasrendi szerzetes Ferrara és Pázmány Péter. Előfordulhat, hogy a négy szobor valahol még ma is létezik. A lépcsőház és az emelet 13 mellszobra túlélte a köztes fél évszázadot. 2000. július 1-jétől a törvény erejénél fogva az épületet vissza kellett szolgáltatni az eredeti tulajdonosnak. Azóta a 116 éves épület falai között ismét a Betegápoló Irgalmasrend budai kórháza múködik. 


\section{Irodalom}

[1] Gömör B. Centenary of the building of Polyclinic of the Hospitaller Brothers of St. John of God in Budapest. [100 éves a Budai Irgalmasrendi Kórház épülete.] Orv Hetil. 2003; 144: 18891890. [Hungarian]

[2] Historia Domus of the Buda Hospital of the Hospitaller Order of Saint John of God. Nemzeti Levéltár, Budapest, 1935. [Hungarian]

[3] Mátyás P. New statues in Buda Hospital of the Hospitaller Order of Saint John of God. [Az Irgalmasok kórházának új szobrai.] Magy Múv. 1935; 11: 297-300. [Hungarian]

[4] Ecsery E. Géza Csorba. [Csorba Géza.] Corvina Kiadó, Budapest, 1978; p. 20. [Hungarian]
[5] Papp Z. Tivadar Kézmárszky. In: Kapronczay K, Vizy ESz. (eds.) Famous Hungarian doctors. Vol. IV. [Kézmárszky Tivadar. In: Kapronczay K, Vizy ESz. (szerk.) Híres magyar orvosok. IV. kötet.] Galenus Kiadó, Budapest, 2003. [Hungarian]

[6] Dollinger Gy. Eighty years from my life. [80 esztendő életemből.] Magyar Traumatológia, Ortopédia, Kézsebészet, Plasztikai Sebészet, Budapest, 1979. Reprint 1929-ből. [Hungarian]

(Gömör Béla dr., Budapest, Árpád fejedelem útja 7., 1023 e-mail: gomorbela@gmrbt.hu)

\section{PÁLYÁZATI FELHÍVÁS}

\section{A MAGYAR PATHOLOGUSOK TÁRSASÁGA (MPT) és a MAGYAR ONKOLÓGUSOK TÁRSASÁGA ${ }^{\circledR}\left(\right.$ MOT $\left.^{\circledR}\right)$ - az Elnökség útján - tudományos tevékenység támogatása céljából meghirdeti a}

\section{9. évi „KROMPECHER ÖDÖN” pályázatot.}

A pályázat/pályamunka témája, címe: „Az emlőrák modern szemlélete"

A pályamunka formája: tanulmány

A pályamunka díjazása: $150000 \mathrm{Ft}$

A pályázat feltételei, benyújtásának és elbírálásának módja A pályázók köre

A pályázatra orvostanhallgatók és fogorvostan-hallgatók nyújthatnak be pályamunkát.

\section{A pályázat terjedelme}

A pályamunka - az irodalommal és a dokumentációval együtt - legfeljebb 80 oldal terjedelmű lehet.

A pályamunka benyújtásának módja

A pályamunkát jeligével kell benyújtani.

A szerző nevét és elérhetőségét (évfolyam, lakcím, telefonszám, e-mail cím) lezárt borítékban - melyen a jelige feltüntetésre kerül - kell mellékelni.

A pályamunkát bekötve kell benyújtani, a címlapon szerepeltetve a „KROMPECHER ÖDÖN PÁLYÁZAT” címet és az évszámot.

A pályamunka szerkezete a tudományos publikációk szerkezetével azonos.

A pályamunka beadási határideje: 2019. november 30.
A pályamunka benyújtásának helye:

Semmelweis Egyetem, II. sz. Pathologiai Intézet (Titkárság) 1091 Budapest, Üllői út 93.

$A z$ értékelés szempontjai: a mű eredetisége, a mű stílusa, szerkezete, a felhasznált irodalom korszerüsége.

\section{A pályázat elbírálásának módja:}

A pályázat kiírói a bírálóbizottság tagjait az aktuális téma szakértői közül választják ki.

A pályázat elbírálásának határideje: 2020. január hó 10.

$\mathrm{Az}$ eredmény kihirdetése az elbírálási határidőt követően, a 2020. évi első Országos Metszetkonzultáción, 2020. január 31-én Krompecher Ödön leszármazottainak, valamint a kíró Társaságok képviselőinek jelenlétében történik.

Az eredményt a kírók a meghirdetéssel azonos módon nyilvánosságra hozzák, továbbá arról a nyertest külön, az elbírálási határidő leteltét követő 15 napon belül írásban is értesítik

\section{Egyéb tájékoztatás}

A bírálóbizottság jogosult a legjobb díjazott pályamunkák szakdolgozatként történő elfogadására javaslatot tenni.

A közzététel (kiírás, eredményhirdetés) a Magyar Onkológia folyóiratban, a MOT $^{\oplus}$ honlapján (www.oncology.hu) és az MPT honlapján (www.pathology.hu) történik.

Budapest, 2019. március 8.

az MPT részéröl:

Dr. Sápi Zoltán

az MPT elnöke

a $\mathrm{MOT}^{\bullet}$ részéröl:
Dr. Zalatnai Attila az MPT fötitkára
Dr. Arató Gabriella az MPT pénztárosa
Dr. Mátrai Zoltán
a MOT elnöke
Dr. Nagy Péter

a MOT főtitkára
Dr. Vincze Borbála

a MOT kincstárnoka 